\title{
The Family Relationships as a Sociolinguistic Marker in the Etiquette Speech of the Aristocracy in the XIX TH Century (Anglo-Russian Parallels)
}

\author{
Sonya Nikolova Hristova \\ Department of "Slavistics", Faculty of Philology, South-West University "Neofit Rilski", Blagoevgrad, Bulgaria \\ Email address: \\ sonja1963@abv.bg \\ To cite this article: \\ Sonya Nikolova Hristova. The Family Relationships as a Sociolinguistic Marker in the Etiquette Speech of the Aristocracy in the XIX TH \\ Century (Anglo-Russian Parallels). International Journal of Language and Linguistics. Vol. 9, No. 4, 2021, pp. 215-220. \\ doi: $10.11648 /$ j.ij11.20210904.21
}

Received: May 6, 2021; Accepted: May 29, 2021; Published: July 27, 2021

\begin{abstract}
The present study is devoted to the sociolinguistic aspect of speech etiquette, illustrated by the description, analysis and comparison of the etiquette speech of the Russian nobility and the English aristocracy in the nineteenth century. The research is carried out in line with sociolinguistics. The sociolinguistic approach allows speech to be considered as a system of social signs, determining the personality, of the communicants and reveal the social aspects of the phenomenon of speech of the aristocracy. We focus our attention on the family relationships as a sociolinguistic marker in the etiquette speech of the aristocracy in the XIX th century and its role and influence on the usage of speech etiquette formulas, because the individual's belonging to a certain social class, his origin, and the environment where one lives, affects his speech; it is focused on the social marker family relations as a regulator in the usage of etiquette forms of the address. The relevance of the subject is determined by the importance of language not only as a complex system but also as a social phenomenon, serving the needs of society; providing communication of this society. And in particular, the family as a platform for collecting empirical material for sociolinguistic study, and object for studying the mutual influences between the speech constants of family members, proving and such a way the importance of etiquette in the communication as a component of the communicative activity of the individual The empirical material of the study is excerpted from the significant works of fiction in the English and Russian art literature.
\end{abstract}

Keywords: Sociolinguistic Marker, Speech Etiquette, Etiquette Forms of Address, Family, Relative Relationships, Aristocracy

\section{Introduction}

Society as a social system and a stable social community depends on equal living conditions, common culture, common moral principles, worldview, and the same political and aesthetic views. The key feature of any society is strict compliance with the rules, obligations, requirements, and if its members do not adhere to the established norms, they are doomed to a negative attitude and even isolation. [1] An individual's belonging to a particular social class, both his origin and the environment in which he lives, affect his speech [2].

The social behaviour of an individual depends on three main factors: social equality; gender-age division of labour and family relationships. This determines the social nature of communication, turning it into a specific one, both for different social classes, gender and age groups, and for members of each family [3]. The complete study of functional language characteristics would be possible if we analyze the influence of sociolinguistic markers on an individual's speech, differences or similarities depending on social status, gender, age, family, education, profession and family relationships, etc.

Modern linguistics differentiates two types of stimuli in the development of a language related to the features of its system:

a. internal or social markers that influence its development;

b. external or functioning of the language.

External language social markers do not directly affect the 
language, but indirectly. According to Polivanov, they accelerate or slow down the course of language evolution, but they cannot change its direction [4].

The successful flow of the communicative process depends on three conditions: a common need and interest in receiving and transmitting information; a common topic of conversation; and a common language. Each country, each social stratum has its traditions, norms and stereotypes, rules of speech communication, combined in one term - speech etiquette. The speech etiquette tolerates changes that occur over time, "survives" all the historical periods of development through which humanity passes, leaving an imprint on it [5].

\section{Research Features}

The focus of the paper is on the speech behaviour of the upper social class in Russia and England-the Russian nobility and the English aristocracy in the XIX century because of the direction of the sociopolitical and cultural life. in both countries is determined by the ruling class. Relations between two countries have centuries-old traditions, the contacts between them are complex caused by the confrontation of the international scene. The anglo-Russian rivalry became the" main axis " of international relations in the nineteenth century. But despite the cool interstate relations, the cultural dialogue between them does not interrupt. The Russian aristocracy meticulously "copies" English manners of behaviour and communication. The study is devoted to aristocratic speech etiquette because the language of the aristocracy has always been associated with a high degree of education and a model of the national culture. Knowledge of these features is a prerequisite for successful interpersonal communication. [6]

The historical background of the study is the nineteenth century because it is a fruitful time for the aristocracy, a time of complete cultural hegemony of the upper class, a time of flourishing for aristocratic literature and culture. This is also the period when the ruling class begins to lose its position, but this process is not instantaneous. The aristocracy has wealth, power, and privilege, and it will be a long time before it becomes a little-known factor in society. [7]

These facts are the basis of our interest in the sociolinguistic aspect of the speech etiquette of the Russian nobility and the English aristocracy in the nineteenth century. It also determines the topicality of the theme, which is also due to the importance of language as a complex system, and a socio social phenomenon that serves the needs of society and "provides" communication between its members; the importance of the etiquette in the communication as an integral part of the communicative activity of the individual, from the contribution of the aristocratic class to the development and preservation of the language. The linguistic taste of this class is considered the standard of correct speech [8].

The subject of the research is the etiquette speech of the Russian nobility and the English aristocracy in the nineteenth century, which includes the usage of etiquette formulas for the address. The subject - is the sociolinguistic aspect of speech etiquette. The emphasis is placed on the role of social markers and, in particular, the regulative role of family relationships as a social marker, important for the selection and usage of the same formulas in both languages - English and Russian.

The hypothesis of the research is formulated based on the concept of the existence of a common core in the sociolinguistic characteristics that determine the aristocratic label of speech in Russia and England in the nineteenth century. In other words, that there are parallels in the use of speech etiquette in the sociolinguistic aspect. Speech etiquette is a "language" with nationally determined social characteristics. [9]. Based on this statement, we assume that, despite the cultural and historical differences and peculiarities of communication styles, there are also similarities in the use of speech etiquette.

Every sociolinguistic study aims to prove that the relations between communicators affect language, that facts of the language function in specific conditions corresponding to the verbal communication [10] The purpose of the research is to establish if there are parallels in the usage of the etiquette formulas in Russian and English speech etiquette in the XIX the century in the sociolinguistic aspect based on works of fiction; to achieve a scientific justification for the hypothesis that sociolinguistic markers affect the etiquette of speech and the speech behaviour of the communicators.

The address is one of the most commonly used communication units associated with speech etiquette and the system of rules of politeness and affability. This is one of the important markers of the social situation, social status, social role, and relations between the participants of the communication. The choice of forms of the address also depends on the equality and inequality between communicators. The main formulas of address, characteristic of Russian and English speech etiquette in the nineteenth century, are:

a. Russian speech etiquette - address by personal and paternal name („имя - отчество“), address by last name, address by first name, ты / Вы.

b. English speech Etiquette - address Madame, Sire, MR, MR, Miss, address by the last name, address by the first name, you / You.

\section{The Etiquette Formulas for Address and the Sociolinguistic Marker "Family Relations" - Influence and Impact}

\subsection{The Sociolinguistic Marker "Family Relationships"- Essence and Types}

In the sociolinguistic marker "Family relations", social relations between communicators are on the level of Family, and the nature of their relations is divided into three types:

A. Inner family relations;

B. Close related relationships; 
C. Family marital relations.

The social connections between communicators follow the model $(\mathrm{S})>(\mathrm{H})$ (speaker - hearer) and therefore between:

A.parents - children - parents; brothers - sisters brothers;

B. relatives / nephew /niece/ - aunt, uncle-nephew /niece/ - relatives /;

C. husband - wife - husband.

What determines the direction of speech behaviour in two directions: your own someone else's; close-distant; familiarstranger.

\subsection{Usage of the Etiquette Formulas of Address Under the Influence of the Sociolinguistic Marker "Family Relations"-Comparative Analysis}

The address by:

$$
\text { "Имя-Отчество” - Mrs., Mr, Madam. Sir }
$$

Close related relationships:

Communicators: relatives (nephew / niece - uncle / aunt nephew / niece)

Model: $(S)>(H)$

Examples:

a/ Племянница (тете) - Марья Дмитриевна! [11]

b/ Niece (to aunt) - My dear, Mrs. Crawley, what a fancy (young Lord Southdown - Mrs. Crawley) [12]

For example, a/ is used the address "имя - отчество", which is typical for the Russian speech etiquette, and in example $\mathrm{b} /$ - the regional name Mr, Mrs, which is typical for the English speech etiquette. Comparative analysis has shown that there is no parallel in the usage of the etiquette formula of address between two examples under the influence of the social marker "family relations" with the communicators - relatives.

The First Name

Inner family relations:

Communicators: parents-children-parents; brotherssisters-brothers

Model: $(S)>(H)$

Examples:

a/ Отеи (сыну) - Аркадий, - сделай одолжение... Аркаша! Аркаша!, [13]

b/ Mother (to daughter) - My darling Cecily, I think there must be the same slight error (Gwendolen - Cecily). [14]

For example, a/ and b/are used as the first name that is typical for both Russian and English speech etiquette. Comparative analysis has shown that there is no parallel in the usage of etiquette formula of address between two examples under the influence of the social marker "family relations" with the communicators - parents-children

Close related relationships:

Communicators: relatives (nephew / niece-uncle / auntnephew / niece)

Model: $(\mathrm{S})>(\mathrm{H})$

Examples:

a/ Дядя (племяннику) - Александр!, [15]

b/ Uncle (to nephew) - Ah, Dorian, I am so glad you take it in that way! I was afraid I would find you plunged in remorse and tearing that nice curly hair of yours. (Uncle George - Dorian), [16]

For example, a/ and b/are used as the first name that is typical for both Russian and English speech etiquette. Comparative analysis has shown that there is no parallel in the usage of etiquette formula of address between two examples under the influence of the social marker "family relations" with the communicators - relatives

Family marital relations:

Communicators: husband - wife - husband

Model: $(S)>(H)$

Examples:

a/ Супруга (супругу) - Теодор, не прогоняйте меня! Теодор! (Теодором она его больие ну называла), (Варвара Лавреикая - Лавреикому), [11]

b/ Wife (to husband) - It seems to lie yesterday, don't it, John ?, (Mrs Sedley to Mr Sedley), [12]

c/ Супруг (супруге) - Софи, дорогая! (С. П. Войнщевы), [17]

d/ Husband (to wife) - My dearest Amelia, you don't know the world. I do (Osborne to Amelia), [12]

For example, a/ and b/are used as the first name that is typical for both Russian and English speech etiquette. For example, c/ also the first-name, typical for the Russian speech etiquette is used the word „дорогая", but an example, d/ also the first-name, typical for the English speech etiquette has used the word „my dearest" Comparative analysis has shown that there is no parallel in the usage of etiquette formula of address between two examples under the influence of the social marker "family relations" with the communicators -wife - husband - wife

$\mathrm{mbl} / \mathrm{Bbl}-\mathrm{You}$

Inner family relations

Communicators: parents - children - parents; brothers sisters - brothers

Model: $(S)>(H)$

Examples:

mbl - You

a/ Дочь (матери) - Tы, мама, помнишь! Это так, мама... (Аня - Любовь Раневская), [18]

b/ Daughter (to mother) - You know, her father was our drawing-master, Mamma, at Chiswick (Amelia to her mother), [12]

In example, a / is used the standard form for the Russian speech etiquette formula - ты. In example b / is used form you=ты typical for the English speech etiquette. Comparative analysis has shown that there is no parallel in the usage of the etiquette formula of address between two examples under the influence of the social marker "family relations" with the communicators - parents-children.

$\mathrm{Bbl}-\mathrm{You}$

a/ Дочь (матери) - Маман, что Выл...? Что это Bbl,... maman? (Надя Михайловна (Наденька) - Марья Михайловна), [15]

b/ Daughter (to mother) - YOU, Ma'am." and have told him that - that I never can become Lady Crawley, (Rebecca 
to her mother), [12]

In example, a / is used the standard form for the Russian speech etiquette formula - ты. In example $b /$ is used form you=Bы typical for the English speech etiquette. Comparative analysis has shown that there is no parallel in the usage of the etiquette formula of address between two examples under the influence of the social marker "family relations" with the communicators - parents-children.

Close related relationships:

Communicators: relatives (nephew / niece - uncle / aunt nephew / niece)

Model: $(S)>(H)$

Examples:

а/ Племянница (Дяде) - Я верю тебе, дядя, мильй дядя ! Опять тыл, дядя ! Дядя, опять тьи! (Аня - Леониду Андреевичу Гаеву), [18]

b/ Племяннииа (Дяде) - Вы, дядечка... дадечка ! (Варя Леониду Андреевичу Гаеву), [18]

c/ Uncle (to niece) - want to see YOU, Miss Becky / You've said so these three months, Becky, (Sir Pit to Rebecca), [12]

d/ Nephew (to aunt) - You see if one plays good music, people don't listen and if one plays bad music people don't talk. (Algernon - Lady Bracknell), [14]

In example, a / is used the standard form for the Russian speech etiquette formula - ты. In example b / is used the standard form for the Russian speech etiquette formula - Вы. In example, c / is used form you=Bы, typical for English speech etiquette. In example, $\mathrm{d} /$ is used form you=ты, when there is a familiar conversationalist, typical for the English speech etiquette. Comparative analysis has shown that there is no parallel in the usage of etiquette formula of address between two examples under the influence of the social marker "family relations" with the communicators - relatives
Family marital relations:

Communicators: husband-wife - husband

Model: $(S)>(H)$

Examples:

a/ Супруг (супруге) - Вы умная женщина, а я давно вас простил, но между нами бездна. (Федор Лаврецкий Варвара Павловна Лаврецккая), [11]

b/ Супруг (супруге) - Ничего ты не знаешь - нечего иначе ты не смотрела так надменно (Софья Егоровна Войниеву), [17]

c/ Husband (to wife) - YOU will let me see you to your carriage, my own darling (George Osborn to Amelia), [12]

d/ Wife (to husband) - Mr. Crawley, you are intoxicated, as usual. (Mrs. Crawley to Mr. Crawley), [12]

In example, a / is used the standard form for the Russian speech etiquette formula - ты. In example b/ is used the standard form for the Russian speech etiquette formula - Вы. In example, c / is used form you=Вы, typical for English speech etiquette. In example, $\mathrm{d} /$ is used form you=ты, when there is a familiar conversationalist, typical for the English speech etiquette. Comparative analysis has shown that there is no parallel in the usage of etiquette formula of address between two examples under the influence of the social marker "family relations" with the communicators - husbandwife-husband.

\subsection{Results of the Comparative Analysis}

Comparative analysis of the formulas of the address present in the speech etiquette of the Russian nobility and the English aristocracy in the XIX century under the influence of social marker "family relations" has shown that:

Table 1. Inner family relations.

\begin{tabular}{|c|c|c|}
\hline Russian Nobility & Inner family relations & English Aristocracy \\
\hline & parents - children & \\
\hline The First Name & & The First Name \\
\hline \multirow[t]{2}{*}{ ты / Вы } & & $\begin{array}{l}\text { You=ты } \\
\text { You=Bы }\end{array}$ \\
\hline & brothers - sisters & \\
\hline The First Name & & The First Name \\
\hline ты & & You=ты \\
\hline
\end{tabular}

Table 2. Close related relationships.

\begin{tabular}{lll}
\hline Russian Nobility & Close related relationships & English Aristocracy \\
\hline & nephew, niece - uncle, aunt & \\
The First Name & & The First Name \\
ты / Вы & & You=ты \\
& & You=Bы \\
\hline
\end{tabular}

Table 3. Family marital relations.

\begin{tabular}{lll}
\hline Russian Nobility & Family marital relations & English Aristocracy \\
\hline & husband - wife - husmand & \\
„имя - отчество“ & & Mr, Mrs, \\
The First Name & & The First Name \\
ты / Вы & & You=ты \\
& & You=Bы \\
\hline
\end{tabular}


The scientific thesis is confirmed that, despite the cultural and historical differences, there are universals in the use of speech etiquette; there is a common core in the sociolinguistic characteristics that determine the aristocratic etiquette speech in Russia and England in the nineteenth century.

\section{Conclusions}

The interaction between language and society is a broad and multi-layered problem. A person is built as a person in the process of socialization with others. Mastering the language requires familiarization with ethical norms, rules for conducting business, and friendly contacts, guarantee a successful communicative process [19]. Sociolinguistic markers have a huge influence on etiquette speech, in the regulation of social relations, and the use of the etiquette formulas, because the language is a system, characterized by openness and predisposition to the influence of the linguistic and extra-linguistic factors.

Specialists in communication theory are interested in the influence of relationships between family members on the nature of their communication. The family is considered as a social phenomenon that has the main features of a social institution and a small social group that implements the need of people for physical and spiritual reproduction, realizing the relationship between the closest relatives. (http:www.referati.org/semeistvoto-kato-socialen-

fenomen/62577/ref.).

Sociology considers the family as a social institute representing the"cell" of society and as a small social intimate group. A feature of the institute „, family“ is that it, on the one hand, reflects the state of society, and on the other - has an impact on it. So, the changes in society entail changes in the family (www.kaminata.net/forum/semeystvoto-kato-socialen-insitutt90045.html)Imad. rijrje).

The consideration of the family in the sociological and sociolinguistic aspect of the socialization of the transfer of knowledge and practical experience, the development of certain value orientation, and a system of norms of behaviour and is the key abutment between them. The family is that small speech community that most influences speech habits. Parents' speech is a model for their children up to 4-5 years old. [20] This is the social basis for maintaining the speech levelling in the family, which is part of these norms. Linguistic criteria correspond to the most important linguistic processes in the family and correlate with the specifics of the family-social and communicative system. The sociology of the family is a field of sociological knowledge, the subject of which is the formation, development, and functioning of family relations in specific and socio-economic conditions.

The family is a field for collecting empirical material for sociolinguistic research, but it is also and the subject of studying the mutual influences between the speech constants of family members, between families and relatives, between spouses, and the clash between features in the speech of individual generations, because the family as a social institute, is the model of family behaviour and communication. [21].

\section{References}

[1] Sociology, electronic journal: Sociology. Reviews on sociology, electronic journal / the second / Society as a social system, Accessed $\quad 18.06 .2017$, http://sociologs.ru/stati/obshestvo.html.

[2] Berezin, F. M., Golovin, B. I. (1979). General azykoznanie. M., 1979, 187-416.

[3] Barber, B (1972: electronic edition) The structure of social stratification and trends in social mobility. // American Sociology, 1972, 15. 02. 2016, http.//scibook.net/raznyihstran- cotsiolodiya/struktura- sotsialnoy-stratifikatciitendentcii - 19840.html.

[4] Polivanov, E. D. (1991). Selected works: Works on Eastern and general linguistics / Editorial Board: I. F. Vardul (pres.). V. M. Alpatov, F. D. Ashnin, Vyach. Vs. Ivanov, L. R. Kontsevich, A. A. Leontiev: Institute of Oriental Studies of the USSR Academy of Sciences-Moscow: Nauka (GRVL), 1991-624 p - - 3000 copies-IBBN 5-02-017118-2, (in trans.) - p. 175.

[5] Baudouin-de-Courtenay (1963). Selected works on general linguistics [Text] - M., AN SSSR 1963-Vol. 1-pp. 98-384.

[6] Liven, D (2000). Aristocracy in Europe 1815-1914-St. Petersburg: Academic Project 2000-pp. 80-84.

[7] Vinogradov, V. V, (1959). On the language of fiction - M., 1959-p. 165.

[8] Ivushkin (1997: electronic edition). The language of the English aristocracy: socio-historical aspect. Volgograd 1997, 10. 05. 2015, http://www.nlr.ru/query -print.php?query $\mathrm{ID}=25573$.

[9] Formanovskaya, N. I. (1987). Formanovskaya, N. I. Russian speech etiquette: linguistic and methodological aspects. - M., 1987-p. 157.

[10] Schweitzer, A. D. (1982), On the problem of social differentiation of language // Questions of Linguistics, 1982No. 5-p. 49.

[11] Turgenev, I. S., "The Noble Nest". 09. July 2015. a/ http://www.library.ru/text/1647/p.46/index.htm/.

[12] Thacerry, W. M., "Vanity fair". 18. August 2015. http://www.gutenberg.org/ebooks/599.

[13] Turgenev, I. S., "Fathers and Children". July 10, 2015. б/ http://www.e-reading.clu/book.php?book=57699.

[14] Wilde, O. "The Importance of Being Earnest". 22 August 2015. b/ http://www.gutenberg.org/files/844/844-h/844-h.htm.

[15] Goncharov, I. A., "Ordinary history". July 12, 2015.http://liberbook.ru/obyknovennaia_istoria_ivan_aleksan drovich_goncharov.

[16] Oskar Wilde "The Picture of Dorian Grey". 24. August 2015. http://www.gutenberg.org/ebooks/790. 
[17] Chekhov, A. P., "Fatherless". July 13, $2015 . \quad$ a/ http://bookmate.com/books/qDKNX5Zo.

[18] Chekhov, A. P. "Cherry Orchard". July 14, 2015. б/ http://librebook.ru/vishnevyi_sad.

[19] Bell, R. Т. (1980). Социолингвистика. - М., 1980, 29. 04. 2015,

http://superlinguist.ru/index.php/option=com_content\&view= article\&id=42:2010-03-20-21-28-21\&catid-6:2009-11-23-13$58 \&$ ttenid $=8$.

[20] Vodenicharov, P (2007). Sociolinguistics. Sofia: IK "Semarsh", 34.

[21] Bernstein, B. M. (1975). Man and the world. Album. M., Soviet artist 1975. - p. 170-225. 